\title{
SOFT SKILLS PROFILE OF VOCATIONAL SCHOOL STUDENTS IN YOGYAKARTA CITY FOR ENTERING THE INDUSTRIAL WORLD
}

\author{
Tri Wulaningrum \\ Universitas Negeri Yogyakarta \\ Samsul Hadi \\ Universitas Negeri Yogyakarta
}

\begin{abstract}
This study aims to determine the profile and how much the level of soft skills of Vocational High School students in Yogyakarta City. This study is survey research. The population of this study was all students grade XI of State Vocational Schools in Yogyakarta City. The sample of this study was 990 students. The data were collected using a questionnaire. The data were then analyzed and presented in a percentage form. The results of the study present that the percentage gain shows the soft skill profile of Vocational High School students in Yogyakarta City in each aspect, namely communication/persuasion skills of $75.19 \%$; performance management skills of $77.22 \%$; self management skills of 70.27\%; interpersonal skills of 78.68\%; leadership/organizational skills of $77.85 \%$; and cultural skills of 75.60\%. Then, the level of soft skills ability of Vocational High School students in Yogyakarta City is generally categorized in medium, which is in the profile range between $M-0.5 S D$ and $M+0.5 S D(M-0.5 S D<x \leq M+0.5 S D)$.
\end{abstract}

Keywords: vocational school students, industrial world, soft skills profile

Permalink: http://dx.doi.org/10.21831/jpv.v9i3.24944

Contact Tri Wulaningrum @triwulaningrum.2017@student.uny.ac.id

EDepartment of Educational Research and Evaluation, Graduate School of Universitas Negeri Yogyakarta J1. Colombo No. 1, Karangmalang, Depok, Sleman, Yogyakarta 55281, Indonesia 


\section{INTRODUCTION}

Community needs always change. One of the dynamic community needs is employment needs, which are related to the availability of jobs and the needs of the workforce. The actual condition shows a disharmony relationship between employment and the needs of labor in Indonesia. Data from the Indonesian Central Bureau of Statistics (2017) state that "....in the past year, unemployment increased by 10.000 people, while the Open Unemployment Rate (Tingkat Pengangguran Terbuka or TPT) fell by 0.11 points".

Those data are a problem for Indonesia. It shows that the implementation of employment policies in Indonesia has not been optimal. Therefore, we need a planned and systematic problem-solving. One of the strategies for solving labor problems is through education.

Educational institutions are institutions that aim to produce quality human resources and superior competency. Thus, the function of educational institutions is to keep the improvement process running well and produce graduates who meet the needs of the community. Educational institutions consist of formal educational institutions, non-formal educational institutions, and informal education institutions. One of the formal education institutions that specifically aims to produce a professional workforce in Indonesia is a vocational education institution held at the secondary education level, namely Vocational High School (Sekolah Menengah Kejuruan or SMK).

The organization of Vocational High School is regulated in the Law of Republic of Indonesia No. 20 of 2003 on National Education System. The legal regulation asserts that "...the construction of Vocational High School in all regions of Indonesia is intended to prepare graduates for being ready to work independently or work in certain industries or agencies that need middle-level labor". Furthermore, the sustainability of vocational schools in Indonesia is also regulated in a national education standard listed in the Regulation of the Minister of Education and Culture No. 34 of 2018 on the national standard of education in Vocational High School. This regulation states that there are minimal criteria regarding the education system at the Vocational High School level in order to achieve the competence of graduates according to the needs of graduate users. Those regulations become not only a legal regulation that must be respected but also the mandate of the state that needs to be guarded and taken care of as well as possible for the welfare of the people in Indonesia.

Vocational High School is one of the alternative government policies in overcoming the problems of labor needs. Therefore, the existence of Vocational High School cannot be deprived of the development of workforce policies. It is in line with the idea of Pardjono, Sugiyono, and Budiyono (2015), which highlights that vocational education cannot be eliminated from the development of the workforce. Although the existence of SMK does not necessarily solve existing problems, through the skills taught to students in SMK, indirectly, it will increase their productivity. It will make vocational graduates have the skills and abilities to create their own jobs. This expectation is in line with the idea of Thompson (1973) stating that vocational education enhances students' skills, which will ultimately increase their productivity.

The existence of Vocational High School and the needs of the workforce are very relevant. The law has ruled Vocational High School as one of the educational institutions responsible for producing mature students who are ready to enter the workforce. In this way, the nation's development efforts will move faster. It is in accordance with Komariah (2010) that Vocational High School is an educational institution that is responsible for preparing students to enter the labor market, which is one of the nation's development efforts.

In fact, graduates of Vocational High School have yet to be able to answer the problems of labor in Indonesia. Supriyadi (2002) reveals that until now, there are still many job market offers that have not been filled. This condition is supported by data published by the Indonesian Central Bureau of Statistics (2017), "...seen from the level of education, TPT for Vocational High School is the highest among other education levels, which is 11.41 percent".

The empirical observation of the Department of National Education (2004), as quoted by Mariah and Sugandi (2010), states that most graduates of Vocational High School (SMK) in Indonesia are less able to adjust to the development of science and technology. Further, graduates of SMK in Indonesia are also less able to develop themselves and careers in the 
places where they work. It shows that graduates of SMK in Indonesia do not yet have mature work-readiness so that their existence has not been able to answer the problems of labor in the country.

Work readiness of someone entering the workforce shows a pattern. The pattern is composed of several factors that are interconnected and influence. Mariah and Sugandi (2010) state that in general, a person's work readiness is composed of three factors. First, physiological factors which involve several aspects, namely age maturity, physical condition, and body organs. Second, the experience factor that contains a learning experience or work that must be owned by a prospective worker. In this work experience factor, a prospective worker is said to have work readiness if he has the ability, knowledge, and skills, or hard skills. Third, psychological factors involving mental, emotional, and social conditions. In this psychological factor contained the ability of soft skills that must be possessed by a prospective worker who has work readiness.

Those three factors show that there is a pattern of relationships between hard skills and soft skills in a person who has work readiness. The relationship between hard skills, soft skills, the world of work, and education can be identified through the ratio of the needs of soft skills and hard skills to the world of work and education.

Soft skills in humans include personal and interpersonal behaviors that develop and maximize human performance, including: "leadership, team building, decision making, initiative, so it does not include technical skills such as financial, computer or assembly skills" (Bernthal, Weaver, \& Wellins, 2002). Kaipa, Milus, Chowdary, and Jagadeesh (2005) mention that soft skills become essential competencies and are the key to success for a workforce in the place where he works and also to develop himself. It certainly strengthens the importance of soft skills for someone in the workforce. By having soft skills attributes that are in harmony with the needs of the world of work, of course, a workforce will be able to survive and develop themselves.

In certain fields of education, such as Vocational High School, soft skills cannot be revoked from the system of education. Vocational High School, as an education system oriented to produce graduates who are ready to work and competitive, always directs graduates to be ready-to-work, smart, have competitive and comparative advantages and have strong character as professional workers.

In fact, a study conducted by Ghufron et al. (2017) found a discrepancy between Vocational High School and the industrial world in terms of understanding soft skills needs. It does not just happen but has a cause. Some other studies, if analyzed, will provide answers to the causes of these inconsistencies. One of them is the study of Neff and Citrin (1999) in Mariah and Sugandi (2010), which reveals the imbalance in the ratio between the needs of soft skills in the world of work and the soft skills taught at school. Neff and Citrin (1999) in Mariah and Sugandi (2010) state that the ratio of the needs of soft skills and hard skills in the workplace/ business that is able to retain someone at work is $80 \%$ determined by the mindset (soft skills) and $20 \%$ determined by technical skills (hard skills). However, the education system runs the opposite, where the ratio of soft skills is only given an average of $10 \%$ in the curriculum. The contradictory comparison between the needs of soft skills and hard skills in the world of work and educational institutions is shown in Figure 1 and Figure 2.

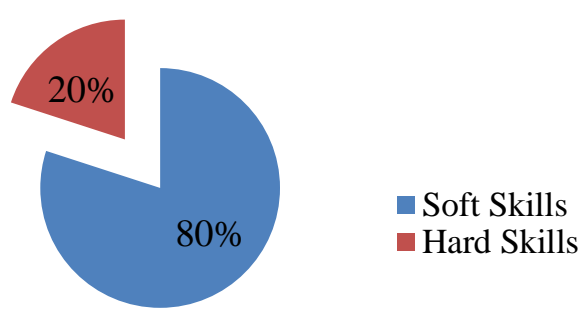

Figure 1. Percentage of Soft Skills as a Component of Success in the World of Work

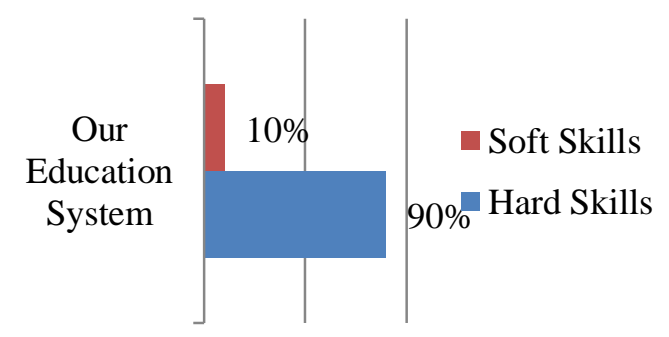

Figure 2. Portions of Soft Skills Given in Education 
Problems do not only stop at the imbalance of the ratio of hard skills-soft skills between the industrial world and the world of education. Another problem is the lack of relevance of understanding between the world of industry and the world of education about the soft skills needed by the world of work. The actual condition shows the gap between the soft skills needed by the business/industry (Dunia Usaha/Dunia Industri or DU/DI) and those taught at school. Suryanto, Kamdi, and Sutrisno (2013) state that there was a mismatch between soft skills needed by the industrial world and those taught at Vocational High School, that (1) the soft skills mostly needed by the industrial world are communication skills; while (2) the most important soft skills to be taught at Vocational High School, according to the teacher, are honesty and good attitude and according to students is time discipline.

Figure 1 and Figure 2, coupled with the analysis of the results of the study related to the lack of relevance of hard skills-soft skills between the world of work and the world of education, illustrate the existence of conditions that should not occur. The world of work and educational institutions should develop with a balanced ratio. The imbalance of the ratio of hard skills and soft skills to educational institutions and the world of work shows a problem that must be solved. In other words, the pattern of imbalances in the ratio of hard skills and soft skills and the incompatibility of understanding of the soft skills needed by the world of work with those given by the education system show that education in Indonesia has not fully been able to improve national development.

The disharmony of hard skills and soft skills ratios, as well as the incompatibility of the understanding of prospective workers' soft skills from vocational education with industrial needs, demands an immediate solution. These problems can be solved if both of them have the required soft skill standards or indicators as well as the soft skill profiles that are currently owned by Vocational High School students. The soft skill profile of Vocational High School students is useful to provide an overview of the readiness Vocational High School students to enter the industrial world, so judgment and recommendations can be made. In fact, there is no official standard released by the government through the Indonesian National Qualifications Framework (Kerangka
Kualifikasi Nasional Indonesia or KKNI) related to the need for industrial workforce soft skills along with the soft skill profile of current Vocational High School students.

The absence of national standards governing the soft skills needed by the industrial world and the lack of studies on soft skills profiles of current vocational students is undoubtedly a challenge for vocational education institutions. Vocational education is required to actively keep abreast of the development of the needs of soft skills in the industrial world and to measure the achievements of their students' soft skills towards existing standards. The soft skill profile of Vocational High School (SMK) students is essential to see. It relates to the relevance of the prospective soft skills of workers with industrial needs. Therefore, today, a study is needed to look at the profiles and achievements of the soft skills of Vocational High School students based on the needs of the industrial world. This study indeed must be preceded by a study of the basic standards of soft skill needs in the industrial world.

Regarding the standard urgency of the needs of soft skills in the industrial world, a soft skills measurement instrument needed by the world of work has been developed, namely Kantrowitz's Soft Skills Performance Measurement (SSPM). Kantrowitz (2005) mentions that there are seven soft skills components that must be possessed by a workforce in order to be able to survive in the workforce, namely (1) communication/persuasion skills, (2) performance management skills, (3) selfmanagement skills, (4) interpersonal skills, (5) leadership/organization skills, (6) political/ cultural skills, and (7) counterproductive skills.

SSPM is a soft skills measurement instrument used in general, not for particular fields of expertise or specific levels of education (Kantrowitz, 2005). It is motivated by the opinion of Boyatzis (1982) in Kantrowitz (2005), who stated that soft skills broadly apply to various jobs. Thus, all fields of work need a tendency for soft skills that can be generalized.

SSPM is used to see the soft skills profile of Vocational High School students. This profile can be used as a reference for detecting soft skills in students. The results of this study can be used as further study material (for example, improving aspects of students' soft skills that are still low). The problem is that SSPM cannot be used directly. Detecting students' 
soft skills will be better if it is adapted to the needs of soft skills in the business world and industry. Ghufron et al. (2017) explain that:

"work culture is soft skills possessed by a group of prospective workers (who are in $S M K)$ in order to be able to optimize their hard skills. The profile of vocational school graduates who have a work culture in harmony with the demands of the industry and or the business world will definitely increase absorption".

The results of a survey conducted by Widarto (2011) show that the current profile of labor needed by the industrial world is a workforce that has strong, soft skills aspects. Widarto (2011) states that there are 13 work cultures (soft skills) needed by the business world and the industrial world, namely: (1) discipline; (2) honesty; (3) commitment: (4) responsibility; (5) confidence; (6) ethics; (7) manners; (8) cooperation; (9) creativity; (10) communication; (11) leadership; (12) entrepreneurship; and (13) organizing.

Based on some of the reviews previously presented, this research was conducted to look at the profile and measure the level of Vocational High School students' soft skills based on industry needs. The instruments developed in this study used SSPM to be adapted to the work culture in Indonesia as a reference in looking at the needs of soft skills in the business world and industry. Soft skills instruments are reduced to six aspects tailored to the work culture in Indonesia. These six aspects are (1) communication/persuasion skills; (2) performance management skills, (3) self-management skills, (4) interpersonal skills; (5) leadership/organization skills, and (6) cultural skills. The selection of Vocational High School students as research respondents was motivated by the main objective of Vocational High School as an educational institution that standardized to produce graduates who were ready to work. The soft skills that must be possessed by a vocational graduate in entering the industrial world are one indicator of work readiness. Data acquisition related to the suitability of Vocational High School graduates' soft skills with the needs of soft industrial sketches, of course, can be used as material for scientific studies in the improvement and development of vocational education systems in Indonesia.

\section{RESEARCH METHOD}

This study is survey research employing a quantitive approach. The research only profiled and examined the level of soft skills Vocational High School students (how high level of soft skills by presenting it in the form of diagrams and numbers with a description in sentence form). The population in this study is all of the students of State Vocational Schools (grade XI) in Yogyakarta City. The sample of this study was 990 students. The sample size is determined based on Roscoe's theory (1975), which is taken 30 students in each department in eight schools. Then, the next step is determining the sample in each department in each school by using simple random sampling. The data collection technique used is questionnaire.

The study used one variable described into several aspects originating from SSPM and reduced to only six indicators: communication/persuasion skills, performance management skills, self-management skills, interpersonal skills, leadership/organization skills, and cultural skills. The data were analyzed descriptively. Analysis was used to calculate the mean, median, mode, standard deviation, data distribution table, profile percentage, and chart categories that show the level of student's soft skills. Profile percentage of soft skills was analyzed using the following formula:

$$
\begin{aligned}
& \text { Profile Percentage }=\frac{n}{N} \times 100 \% \\
& \mathrm{n} \quad=\text { empiric score } \\
& \mathrm{N} \quad=\text { Ideal Score }
\end{aligned}
$$

Table 1. Calculation Formulas for Soft Skills Level Categories

\begin{tabular}{ll}
\hline $\begin{array}{c}\text { Category } \\
\text { Level }\end{array}$ & \multicolumn{1}{c}{ Calculation Formula } \\
\hline Very Low & $x \leq M-1,5 S D$ \\
Low & $M-1.5 S D<x \leq M-0.5 S D$ \\
Medium & $M-0.5 S D<x \leq M+0.5 S D$ \\
High & $M+0.5 S D<x \leq M+1.5 S D$ \\
Very High & $M+1.5 S D<x$ \\
\hline $\mathrm{M}=$ Average of Ideal Score $=\frac{1}{2}($ ideal maximum score + \\
ideal minimum score $)$ \\
$\mathrm{SD}=$ Ideal Standard Deviation $=\frac{1}{6}$ (ideal maximum score - \\
ideal minimum score $)$
\end{tabular}

The level category of soft skills, according to Azwar (2012), is divided into five: very low, low, medium, high, and very high. These five categories are obtained through the calculations presented in Table 1. 


\section{RESULTS AND DISCUSSION}

The results of the study are presented in the form of the results of calculations of central tendencies (mean, median, mode) and data distribution. The presentation of data distribution includes variants and standard deviations. Next is the presentation of the size of the frequency distribution and interpretation of the research data, where interpretation refers to five-level categories, namely, very low, low, medium, high, and very high. The description of the variable data on soft skills of students of State Vocational Students in Yogyakarta City consists of six aspects: (1) communication/persuasion skills, (2) performance management skills, (3) self management skills, (4) interpersonal skills, (5) leadership/organization skills, and (6) cultural skills.

Before the presentation of the profile and level of soft skills in each aspect, it will first be presented the profile of Vocational High School students' soft skills in Yogyakarta City in general. In general, the profile of Vocational High School student soft skills is shown by the percentage gain in each aspect, namely communication/persuasion skills of $75.19 \%$; performance management skills of $77.22 \%$; self management skills of $70.27 \%$; interpersonal skills of $78.68 \%$; leadership/organization skills of $77.85 \%$; and cultural skills of $75.60 \%$. This percentage number does not indicate the number of students, but rather the score of achievement of soft skills in each aspect. The general profile of Vocational High School students' soft skills is presented in Figure 3.

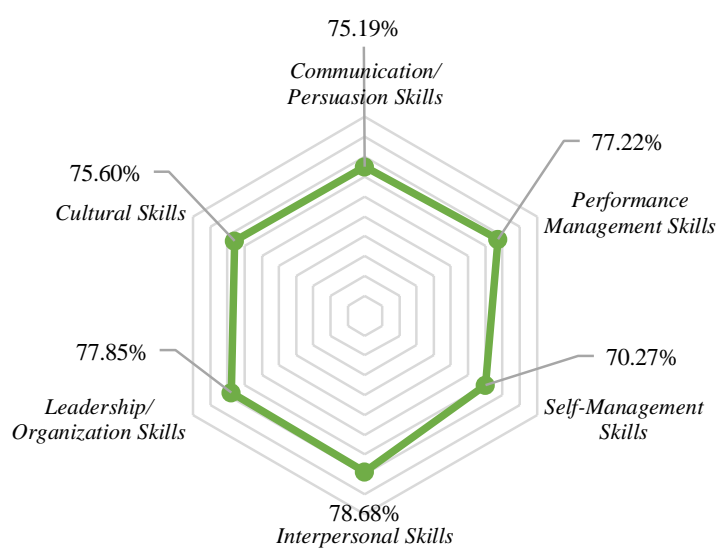

Figure 3. Profile of Soft Skills of Vocational High School (SMK) Students in Yogyakarta City
Figure 3 shows that interpersonal skills are aspects of soft skills that have the highest percentage achievement, while the lowest percentage achievement is in aspects of self-management skills. In other words, in Yogyakarta City, the most prominent soft skills of Vocational High School students are on the aspects of interpersonal skills. Based on the achievements of the highest to lowest percentage, the soft skills aspect in the profile of Vocational High School soft skills in Yogyakarta is written as follows: (1) interpersonal skills; (2) leadership/organization skills; (3) performance management skills; (4) cultural skills; (5) communication/persuasion skills; (6) selfmanagement skills.

Table 2. Comparison of the Aspect Levels of Soft Skills of Students of State Vocational School in Yogyakarta City

\begin{tabular}{lcc}
\hline \multicolumn{1}{c}{ Aspects of Soft Skills } & $\begin{array}{c}\text { Average } \\
\text { Values }\end{array}$ & Rank \\
\hline Interpersonal Skills & 3.15 & 1 \\
Leadership/organization Skills & 3.11 & 2 \\
Performance management skills & 3.09 & 3 \\
Cultural skills & 3.02 & 4 \\
Communication/persuasion skills & 3.01 & 5 \\
Self management skills & 2.81 & 6 \\
\hline
\end{tabular}

The same sequence of the highest and lowest soft skills aspects was also obtained through the comparison of each aspect's average value. Table 2 shows the order of soft skills aspects of students of Vocational High School in Yogyakarta City viewed from the average value. Furthermore, the levels of Vocational High School students' soft skills in Yogyakarta are presented in more detail in each aspect.

\section{Interpersonal Skills}

Interpersonal skills measurement of students of Vocational High School in Yogyakarta City used 20 questionnaire items. The ideal maximum score on this aspect is 80 , and the ideal minimum score is 20 . The average score of students in this aspect is 62.94 , with a maximum score of 80 and a minimum of 23. The standard deviation in this aspect is 7.85. Based on the calculation results using SPSS software, the percentage of score tendency in the interpersonal skills aspects of the students of Vocational High School in Yogyakarta City can be seen in Figure 4. 


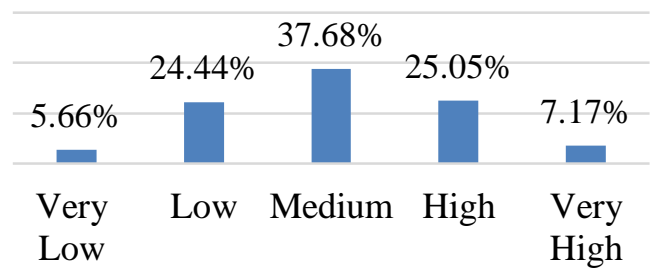

Figure 4. Interpersonal Skills Graph

Figure 4 shows that in the interpersonal skills aspect, as many as $5.66 \%$ of Vocational High School students in Yogyakarta have very low levels; $24.44 \%$ at the low category level; $37.68 \%$ is in the medium category level; $25.05 \%$ at the high category level; and $7.17 \%$ at the very high category level. These results indicate that the level of achievement of Vocational High School students' soft skills in Yogyakarta city is generally at the level of achievement of the medium.

\section{Leadership/Organization Skills}

Leadership/organization skills measurement of students of Vocational High School in Yogyakarta City used questionnaires as many as 17 items. The ideal maximum score on this aspect is 68 , and the ideal minimum score is 17 . The average score of students in this aspect is 52.94 , with a maximum score of 68 and a minimum of 17. The standard deviation in this aspect is 7.33. Based on the calculation results using SPSS software, the percentage of score tendency in the leadership/organization skills aspects of the students of Vocational High School in Yogyakarta City can be seen in Figure 5.

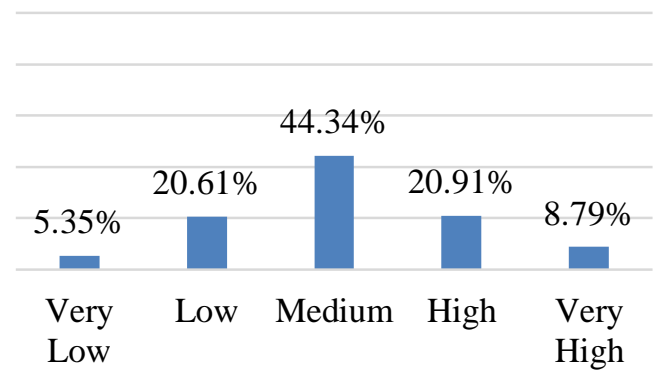

Figure 5. Leadership/Organization Skills Graph
Figure 5 shows that in the aspect of the leadership/organization skills, 5.35\% of Vocational High School students in Yogyakarta have very low levels of achievement; $20.61 \%$ at the low category level; $44.34 \%$ is in the medium category level; $20.91 \%$ at the high category level; and $8.79 \%$ at the very high category level. These results indicate that the level of achievement of Vocational High School students' soft skills in Yogyakarta on aspects of leadership/organization skills, in general, is at the level of achievement of the medium.

\section{Performance Management Skills}

The masurement of performance management skills of students of Vocational High School in Yogyakarta City used questionnaires as many as 21 items. The ideal maximum score in this aspect is 84 , and the ideal minimum score is 21 . The average score of students in this aspect is 64.86 , with a maximum score of 84 and a minimum of 21 . The standard deviation in this aspect is 7.88. Based on the calculation results using SPSS software, the percentage of score tendency in the performance management skills aspects of the students of Vocational High School (SMK) in Yogyakarta City can be seen in Figure 6.

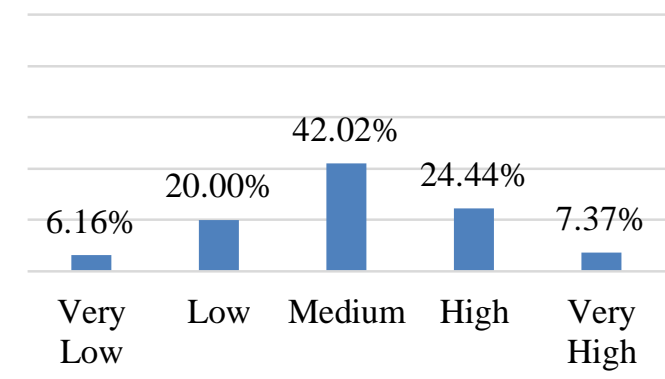

Figure 6. Performance Management Skills Graph

Figure 6 shows that in the aspect of performance management skills, $6.16 \%$ of Vocational High School students in Yogyakarta have very low levels of achievement; $20 \%$ are in the low category level; $42.02 \%$ is in the level of the medium category; $24.44 \%$ at the high category level; and $7.37 \%$ at the very high category level. These results indicate that the achievements of Vocational High School students' soft skills in aspects of management skills performance, in general, are at the level of medium achievement. 


\section{Cultural Skills}

Cultural skills measurement of students of Vocational High School in Yogyakarta City used 13 questionnaire items. The ideal maximum score in this aspect is 52 , and the ideal minimum score is 13 . The average score of students in this aspect is 39.31 , with a maximum score of 52 and a minimum of 16 . The standard deviation in this aspect is 5.03. Based on the calculation results using SPSS software, the percentage of score tendency in the cultural skils aspects of the students of Vocational High School (SMK) in Yogyakarta City can be seen in Figure 7.

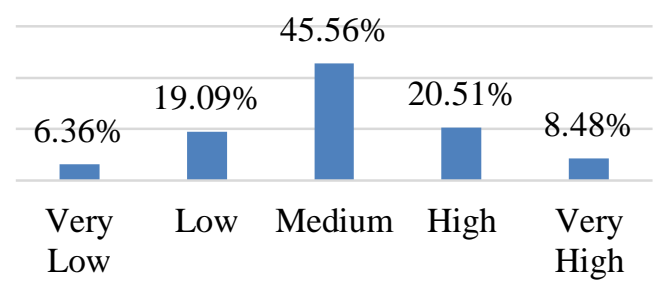

Figure 7. Cultural Skills Graph

Figure 7 shows that in the cultural skills aspect, as much as $6.36 \%$ of Vocational High School students in Yogyakarta have very low levels of achievement; $19.09 \%$ is in the low category level; $45.56 \%$ are in the medium category level; $20.51 \%$ at the high category level; and $8.48 \%$ at the very high category level. These results indicate that the achievements of Vocational High School students' soft skills in the city of Yogyakarta are generally at the medium level.

\section{Communication/Persuasion Skills}

Communication/persuasion skills measurement of students of Vocational High School in Yogyakarta City used 12 questionnaire items. The ideal maximum score on this aspect is 48 , and the ideal minimum score is 12 . The average score of students in this aspect is 36.09 , with a maximum score of 48 and a minimum score of 15 . The standard deviation in this aspect is 4.73. Based on the calculation results using SPSS software, the percentage of score tendency in the communication/persuasion skills aspects of the students of Vocational High School in Yogyakarta City can be seen in Figure 8.

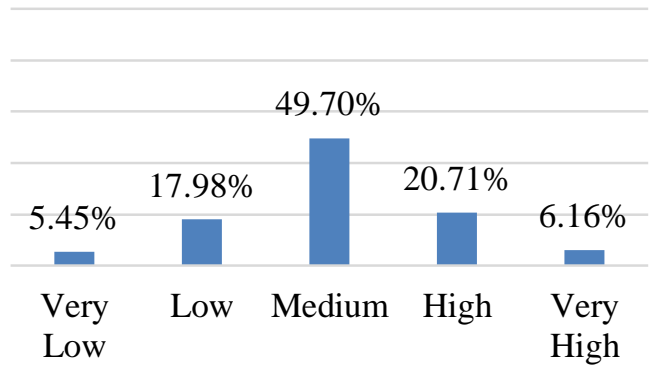

Figure 8. Communication/Persuasion Skills Graph

Figure 8 shows that in the aspect of communication/persuasion skills, $5.45 \%$ of Vocational High School students in Yogyakarta have a very low level of soft skills achievement; $17.98 \%$ at the low category level; $49.70 \%$ at the medium category level; $20.71 \%$ is in the high category level; and $6.16 \%$ at the very high category level. These results indicate that the achievements of the vocational students' soft skills in the aspects of communication/persuasion skills are generally at the medium level.

\section{Self Managements Skills}

Self-management skills measurement of students of Vocational High School (SMK) in Yogyakarta City used ten questionnaire items. The ideal maximum score on this aspect is 40 , and the ideal minimum score is 10 . The average score of students in this aspect is 28.11, with a maximum score of 40 and a minimum of 14. The standard deviation in this aspect is 3.86. Based on the calculation results using SPSS software, the percentage of score tendency in the self-management skills aspects of the students of Vocational High School in Yogyakarta City can be seen in Figure 9.

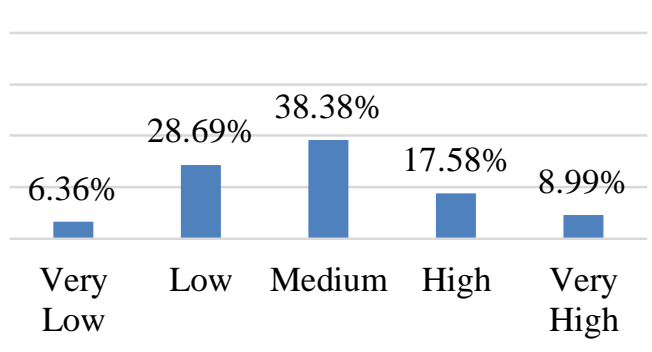

Figure 9. Self-Management Skills Graph 
Figure 9 shows that in the aspect of selfmanagement skills, $6.36 \%$ of SMK students in Yogyakarta have very low levels of achievement; $28.69 \%$ is at the low category level; $38.38 \%$ is in the medium category level; $17.58 \%$ at the high category level; and $8.99 \%$ is in the very high category level. These results indicate that the achievements of Vocational High School students' soft skills in Yogyakarta on the aspects of self-management skills, in general, are at the medium level.

The existence of soft skills in Vocational High School (SMK) students to enter the industrial world is very important. It is in line with Evenson (1999) that soft skills have been around for a long time in the business and education environment, in company meetings, and curriculum development.

The soft skills of Vocational High School (SMK) students in Yogyakarta in this study were measured based on six aspects, namely, communication/persuasion skills, performance management skills, self-management skills, interpersonal skills, leadership/ organization skills, dan cultural skills. These aspects are aspects obtained through the theory of Kantrowitz (2005).

Furthermore, six major aspects of soft skills in this study have a framework in general. Aspect 1 is labeled as Communication/ Persuasion Skills. It includes behaviors generally aimed at communicating with others, in terms of asking questions, delivering presentations, influencing others, negotiating, persuading, and seeking information. Aspect 2 is labeled as Performance Management Skills. This cluster encompasses behaviors involved in managing the work of others and managing projects. It includes activities such as analyzing needs, articulating expectations, coaching/ training, developing others, and evaluating performance. Aspect 3 is labeled Self-Management Skills, which are aimed at managing, controlling, and regulating one's own behaviors. This aspect includes acting calm during a crisis, controlling emotions, and tolerating stress. Aspect 4 is labeled Interpersonal Skills, which describe work behaviors that involve interacting with others in work situations. It includes acting courteous and respectful, building a network, complimenting others on valid points, compromising, developing rapport, and reconciling opinions. Aspect 5 is called Leadership/Organization Skills, which involve en- visioning and implementing plans and strategies. This aspect includes developing strategies/plans, showing a vision, providing solutions, and setting goals. Aspect 6 is termed Political/Cultural Skills and involves demonstrating competence with respect to functioning in the culture and climate of an organization. This aspect includes behaviors such as adapting to environments and people, adjusting a message to an audience, learning unwritten rules, and modifying reactions to fit the culture.

The six aspects of soft skills, according to Kantrowitz (2005), have related to other theoretical soft skills aspects, one of which is Robles (2012). In more detail, Robles (2012) states that there are ten aspects of soft skills needed to enter the workforce, namely: (1) communication, (2) courtesy; (3) flexibility; (4) integrity; (5) interpersonal skills; (6) positive attitude; (7) professionalism; (8) responsibility; (9) teamwork; and (10) work ethic. If analyzed, between Kantrowitz (2005) and Robles (2012), there are two similar aspects related to the needs of the workforce's soft skills, namely communication skills and interpersonal skills aspects.

The results of the study indicate that the level of soft skills of Vocational High School (SMK) students in Yogyakarta City is generally categorized as medium. If viewed from the level of student's soft skills in each aspect, the highest soft skills of the vocational student in Yogyakarta City is interpersonal skills with the percentage of the profile of $78.68 \%$; and the lowest aspect of the student's soft skills in Yogyakarta City is self-management skills with the percentage of the profile of $70.27 \%$. If sorted from aspects that have the best profile (high percentage), the profile of vocational students' soft skills in Yogyakarta is (1) interpersonal skills; (2) leadership/organization skills; (3) performance management skills; (4) cultural skills; (5) communication/persuasion skills; and (6) self management skills.

Based on the above sequence, it is known that the best soft skills in vocational students in Yogyakarta City are about abilities in work behaviors that involve interacting with others in work situations. It includes acting courteous and respectful, building a network, complimenting others on valid points, compromising, developing rapport, and reconciling opinions. Meanwhile, the soft skills with the lowest achievements include the ability in 
managing, controlling, and regulating one's own behaviors, acting calm during a crisis, controlling emotions, and tolerating stress.

The results show that, in general, vocational students in Yogyakarta City were at the level of achievement of the medium in all aspects. Referring to the results of the study, it can be said that in the soft skills variable, SMK students in Yogyakarta City are considered to have the readiness to enter the industrial world. The level of vocational soft skills of students in the medium category can be used as a supporting factor in entering the workforce. This is in accordance with Pusriawan and Soenarto (2019) that it is not only hard skills that students must have, but also soft skills. One form of soft skills is employability skills (Pusriawan \& Soenarto, 2019). Employability skills of the students of State Vocational Schools should be a supporting factor for students to get decent work and in accordance with their competency skills so that stakeholders can really use it well (Pusriawan \& Soenarto, 2019).

Pusriawan and Soenarto (2019) state that employability skills are non-technical skills needed by each individual, both job seekers and workers themselves, that can be transferred and learned through both habituation and training. There are nine aspects of employability skills according to Pusriawan and Soenarto (2019), namely: (1) communication skills; (2) collaboration skills with TIM; (3) problemsolving skills; (4) skills in taking initiatives and trying; (5) skills in planning and organizing activities; (6) self management skills; (7) skills in learning; (8) skills in using technology; and (9) occupational health and safety skills.

The results of the study show that in vocational students in Yogyakarta City, the interpersonal skills aspects became the most prominent aspect. The existence of interpersonal skills aspects as the aspect with the highest achievement projects that vocational students in Yogyakarta City have representation with the needs of today's industry. It is in line with Sheikh (2009) that interpersonal skills are the most critical skills at all levels. In addition, Klaus (2010) states that companies assess employee interpersonal skills as more important than their analytical abilities. Bernthal et al. (2002) state that soft skills include personal and interpersonal behaviors that develop and maximize human performance, which include: "leadership, team building, decision making, initiative, so it does not include technical skills such as financial, computer or assembly skills".

Nowadays, it is increasingly realized that soft skills in vocational students are so important in preparing graduates who are in accordance with the vision and mission of the Vocational School. It is evidenced by several studies related to the development of soft skills learning models conducted at Vocational High School. Amin, Zamroni, and Sofyan (2017) developed a soft skills learning model integrated with the learning program. Furthermore, Hamidah (2013) also developed a soft skills learning model that is integrated into vocational students in culinary study programs, which is a hypothesis learning model. This learning model allows the mastery of soft skills in students to be consistent. The integration process can start from student learning design, ongoing implementation, and evaluation based solely on continuous improvement or performance management. Related to the importance of soft skills to prepare students to enter the workforce, Abdullah-Al-Mamun (2012) states that education institutions should present a wellformed learning experience with enhancing graduate employability as a core constituent where soft skills are embedded in the curriculum process.

\section{CONCLUSION}

The level of soft skills of Vocational High School students in Yogyakarta is generally categorized at a medium level. If viewed from the level in each aspect, there are communication/persuasion skills of $75.19 \%$; performance management skills of $77.22 \%$; selfmanagement skills of $70.27 \%$; interpersonal skills of $78.68 \%$; leadership/ organizational skills of $77.85 \%$; and cultural skills of $75.60 \%$.

The highest soft skills of vocational students in Yogyakarta are in aspects of interpersonal skills with a percentage of $78.68 \%$ with an average value of 3.15 , and the lowest aspect of soft skills of vocational students in Yogyakarta is on the aspect of self-management skills with a percentage of $70.27 \%$ with an average value of 2.81. The existence of the level of soft skills of students in the medium in vocational students of Yogyakarta City should be a supporting factor for students to get decent work and in accordance with their competency skills so that stakeholders really use it well. 


\section{ACKNOWLEDGMENTS}

The researchers thank the mentors and academic members of the Educational Research and Evaluation Study Program (Graduate School of Universitas Negeri Yogyakarta) for the provided input so that this research could be completed.

\section{REFERENCES}

Abdullah-Al-Mamun, M. (2012). The soft skills education for the vocational graduate: Value as work readiness skills. British Journal of Education, Society \& Behavioural Science, 2(4), 326-338. https://doi.org/10.9734/BJESBS/2012/1 858

Amin, M., Zamroni, Z., \& Sofyan, H. (2017). A model of soft skill instruction based on the local culture for vocational teacher candidates in North Sumatra. Jurnal Pendidikan Vokasi, 7(2), 127138. https://doi.org/10.21831/jpv.v7i2. 14902

Azwar, S. (2012). Penyusunan skala psikologi (2nd ed.). Yogyakarta: Pustaka Pelajar.

Bernthal, P., Weaver, P., \& Wellins, R. (2002). The state of e-learning: Developing soft skills. Bridgeville, PA: HR Benchmark Group.

Central Bureau of Statistics. (2017). Agustus 2017: Tingkat pengangguran terbuka (TPT) sebesar 5,50 persen. Retrieved May 27, 2018, from https://www.bps. go.id/pressrelease/2017/11/06/1377/agu stus-2017--tingkat-pengangguran-terbu ka--tpt--

Evenson, R. (1999). Soft skills, hard sell. Techniques: Making Education and Career Connections, 74(3), 29-31.

Ghufron, A., Suwarna, S., Ismara, I., Marzuki, M., Mutaqin, M., \& Pramono, H. S. (2017). Penerapan budaya kerja industri di Sekolah Menengah Kejuruan. Yogyakarta: UNY Press.

Hamidah, S. (2013). Model pembelajaran soft skill terintegrasi pada siswa SMK program studi keahlian tata boga. Jurnal Pendidikan Vokasi, 2(1), 53-62. https://doi.org/10.21831/jpv.v2i1.1016
Kaipa, P., Milus, T., Chowdary, S., \& Jagadeesh, B. V. (2005). Soft skills are smart skills. Retrieved April 16, 2019, from http://kaipagroup.com/articles/soft skills.pdf

Kantrowitz, T. M. (2005). Development and construct validation of a measure of soft skills performance. Doctoral thesis. Georgia Institute of Technology.

Klaus, P. (2010). Communication breakdown. California Job Journal, 28, 1-9.

Komariah, K. (2010). Memimpikan SMK di masa depan. In Seminar Nasional Prospek Pengembangan Pendidikan Vokasional dalam Era Globalisasi (pp. 127-132). Bandung: Culinary Education Study Program, FPTK, Universitas Pendidikan Indonesia.

Law of Republic of Indonesia No. 20 of 2003 on National Education System (2003).

Mariah, S., \& Sugandi, M. (2010). Kesenjangan soft skills lulusan SMK dengan kebutuhan tenaga kerja di industri. Jurnal Inovasi Dan Perekayasa Pendidikan, 3(1), 1-22.

Pardjono, P., Sugiyono, S., \& Budiyono, A. (2015). Developing a model of competency and expertise certification tests for vocational high school students. REiD (Research and Evaluation in Education), 1(2), 129-145. https:// doi.org/10.21831/reid.v1i2.6517

Pusriawan, P., \& Soenarto, S. (2019). Employability skills of vocational school students in Palu City for entering the work world. Jurnal Pendidikan Vokasi, 9(1), 33-42. https://doi.org/ 10.21831/jpv.v9i1.23351

Regulation of the Minister of Education and Culture No. 34 of 2018 on the national standard of education in Vocational High School (2018). Republic of Indonesia.

Robles, M. M. (2012). Executive perceptions of the top 10 soft skills needed in today's workplace. Business Communication Quarterly, 75(4), 453-465. https:// doi.org/10.1177/1080569912460400 
Sheikh, S. (2009). Alumni perspectives survey: Comprehensive data report. Reston, VA: Graduate Management Admission Council.

Supriyadi, D. (2002). Sejarah pendidikan teknologi dan kejuruan di Indonesia. Jakarta: Departemen Pendidikan Nasional, Direktorat Pendidikan Menengah Kejuruan.

Suryanto, D., Kamdi, W., \& Sutrisno, S. (2013). Relevansi soft skill yang dibutuhkan dunia usaha/industri dengan yang dibelajarkan di Sekolah Menengah Kejuruan. Teknologi Dan Kejuruan, 36(2), 107-118. Retrieved from http:// journal.um.ac.id/index.php/teknologikejuruan/article/download/3811/709

Thompson, J. F. (1973). Foundation of vocational education: Social and philosophical concepts. Englewood Cliffs, NJ: Prentice-Hall.

Widarto, W. (2011). Pentingnya pendidikan soft skills bagi siswa SMK dalam menyiapkan tenaga kerja yang diperlukan dunia usaha dan dunia insdustri. Yogyakarta: LPPM UNY. 